\title{
Within a Room
}

\author{
Lynne Wanamaker
}

Lynne Wanamaker is an early childhood educator in two family drop-in programs in British Columbia. She worked for many years in Ontario with families with preschool-aged children providing consultation to educators regarding the children's inclusion in early childhood settings in their communities. Since 2011, Lynne has been a participant-educator in the Community Early Learning and Child Care Facilitators Project in the University of Victoria's Unit for Early Years Research and Development's Investigating Quality Project. Lynne is visited by a pedagogical facilitator from the project each week at the family drop-in program and she participates in monthly learning circles. Her interests include engaging with pedagogical narrations as critically reflective encounters and openings. She strives to continually practice from an ethics of resistance and an ongoing desire for equity and social justice. Email: lwanamaker@sd63.bc.ca

When any of us must endure inequity or injustice, when there are those who are not heard, as human beings we are all diminished. (Cannella, 1998, p.179)

In the face of an injustice toward a child, what is the responsibility of an early childhood educator? What are the risks if we speak out? What are the risks if we remain silent, if we do nothing? "Courage, Hannah Arendt (1958/1998) suggests, which we often think of as a quality of the 'hero,' is already present in the willingness to act and speak, to insert oneself into the world and begin a story" (Berger, 2010, p. 73).

"Lynne is conscientious in her work but she is shy." I find it quite interesting that this comment/label written about me on my report card 52 years ago by my kindergarten teacher entered my thoughts out of somewhere while I was contemplating how to tell this particular story about taking risks in my practice as an early childhood educator, and how I let go of normal. If indeed I am normally shy, I most definitely let go of my personal and professional normal in a family drop-in program in which I am the only early childhood educatorfacilitator. It happened one busy morning in front of parents, grandparents, care providers, and children from infancy to five years old. People had been engaged in relation with each other and the mostly unconventional materials in the intentionally unstructured, untimed, and nontraditionally run program that is situated within a room in an urban elementary school.

I also find it interesting that my story about letting go of normal involves a child about whom adults have asked me if there is, and told me that there is, "something wrong with him." Can they actually be saying that he is not right, that he is abnormal? Thankfully, this child has been so intensely involved in his wonderful moments of intra-action with the materials that he has not noticed that for more than a year he has been, incredulously, on the receiving end of adults' overt disrespect, evidenced in their rolling eyes and stares on-the-edgeof glares, in their disapproving looks, and, shockingly, in the mouthed word "crazy" from one adult to another. The child's mother and father, on the other hand, have noticed — and so have I, numerous times.

I ponder: What is it that circulates in our society that manifests itself in such negative responses toward a child engaged in intra-action with materials he encounters within a room in his community, within a room in which I have consciously chosen to let go of the traditional, practicing instead from a pedagogy of listening (Rinaldi, 2006), an ethics of resistance (Lenz Taguchi, 2010), an ethics of care (Dahlberg \& Moss, 2005), and an ongoing desire for social justice and equity.

Within a room beside an educator who has created a space in which lines of flight (Deleuze \& Guattari, 1987) are possible, having intentionally let go of the ideas, conditions, and practices traditionally thought to promote and denote "quality" in early childhood settings.

Within a room to which this child has come with his father, mother, or grandmother up to three or four times each week for almost all of his life. This child knows this room, having sat on his father's lap and looked about in it, crawled and walked in it, made inquiries and discoveries within in it, and intra-acted with provocations and materials that called out to him within it.

Within a room that this child's parents know as a place of theirs, as well as their child's. A place where they know their image of children 
as being capable, competent, and natural researchers matches with the image of children held by the educator (Government of British Columbia, 2008; Rinaldi, 2006). A place where they know that time and space is given to the ideas of their child, and others' children. A place in which this child's parents and I have frequently engaged in critically reflective dialogue about children, childhood, and learning, as well as about society, power relations, and freedom.

Within a room in which this child can come upon a three-foot-long birch branch on a shelf, pick it up, say aloud to no one and to everyone that this is "my axe for chopping down trees" as he walks across the room, with the branch held in his hands and resting on his shoulder, over to another child and asks, "Do you want to play chopping down trees?"

Within a room beside an educator who let go of her personal and professional normal and risked the same behaviour that had been directed at the child being directed at her - rolling eyes, stares on-the-edge-of glares, disapproving looks, and the mouthed word "crazy"- when I loudly declared to them all, "There is a game of chopping down trees with axes going on over here. I know we are in a small space, but there is no way in the world I am going to shut this down. The children are asking some very thoughtful questions, like, 'Why do trees grow bigger than people?' and I want to give space to this encounter." The not quite four-year-old child asked me this question as we sat side by side, waiting for another child who had said he would play chopping down trees with axes when he was finished what he was doing. I responded: "That is a really deep question. I don't know why trees grow bigger than people." In the silence between us that followed my response, I could not have felt a deeper connection with, affection for, and affinity with this child.

Upon critical reflection a day after this event, I recognized that this child and our relationship over the past three years played a significant part in giving me, a constantly becoming educator, the courage to stand up and declare to (some disapproving) adults that I am making space for somethings, and somebodies, in this someplace.

I am making space within a room that happens to be in a location and time in a society that resists, and at times opposes, what I choose to have this someplace room be about. Within a room in a society that operates from a discourse of valuing order and normal.

Within a room that rejects the untruth of a universal child, that rejects the belief that children need to be powered over and their ideas disregarded, all in the quest to shape, bend (break?) and make children into model future citizens of the world. Within a room beside an educator who is beginning to understand more deeply how power relations operate and circulate in society and the institutions within it (MacNaughton, 2005).

What is it that we want, now and in the future, for children and society (Dahlberg, Moss, \& Pence, 2013)?

I wonder what my kindergarten teacher might report about me now. Maybe that "Lynne is a conscientious worker who is shy but will risk taking a public stand for children and what she believes in, even though it is not of the current popular consensus." What do we do, now that we have heard this story? Whose story is it? And who is the "hero" in this story? Reflecting with Arendt's suggestion in Iris Berger's (2010) quote, let us consider that this child is the "hero" in this story, not the educator who spoke out.

Let us imagine what the individual rooms in our preschools and schools might look like, for all of us, if our choices and decisions were all guided by equity and social justice in caring, responsible communities (Cannella, 2008). Then would there be a room within which a child could run exuberantly across it, flapping long feathers in his arms and declaring, "I'm a fast eagle!" as he runs, without an adult physically impeding his flight? Would there be a room within which this same child could, minutes later, come upon a branch, pick it up, walk across a room of people with it over his shoulder, without being glared at, then ask and wait for another child to play chopping down trees with him?

I want to be free to work as an early childhood educator within a room in which I can bear witness to a three-year-old child asking me the question "Why do trees grow bigger than people?" A question that at 58 years old I have never, ever thought about. I want to work as an early childhood educator within a room in which these unpredictable, precious, and astounding moments are free to come into being. I do not want children being disrespected, their ideas and movements being oppressed to the point that I am compelled to make the choice to interrupt everyone and power-over some disapproving adults with my words that "there is no way in the world I am going to shut this down" and that "I want to make space for this encounter."

I continue to ask myself why I spoke out. Was it for this child? Did he really need me to speak up for him? Was it so this child's parent would feel supported by me in that moment? Was it for me, explaining my action, so I would not feel negatively judged by the disapproving others for not controlling (and in their mind fixing) this child by stopping him from stacking some wooden tree blocks up 
high and swinging an "axe" to "chop" them down? Why would I stop this child who capably, competently, and confidently moves with a "willingness to act and speak, to insert [him]self into the world and begin a story" (Berger, 2010, p. 73)?

Let us consider deeply what Gaile Cannella (2008) asserts:

To reconceptualize a field in which social justice and hearing the voices of younger human beings are the foundation, we must be willing to expand our possibilities, to go beyond the ways that we have been taught to perceive. My colleagues have disagreed with these radical ideas for early childhood education, calling them "too revolutionary." Some believe that the ideas can cause trouble. I believe that we want to cause trouble, that we need to transform ourselves into revolutionary activists for social justice and care, not simply for younger human beings, but for all of us. (p.173)

Within a room in which the pedagogical narrations I have written sit upon our walls and shelves in open invitation to others to read and think with, how can I make more broadly visible to the hundreds of adults who come into this family drop-in the values, beliefs, philosophies, discourses, and pedagogies I intentionally choose to practice with, and why? My displaying of pedagogical narrations, along with my desire to make my choices in practice more visible, is not done with the intention of making others think the same way I do, but rather "for stirring the wind of thought" (Berger, 2015) within us, expanding our perspectives and generating ongoing, critical dialogue and debate about important issues such as race, class, gender, and age.

Drawing on Pinar (1994), Cannella (2008) posits that "only when we are willing to transform ourselves and our work do we have the possibility of transforming society" (p. 173). As an early childhood educator-citizen, I am committed to doing all that I can, within a room and beyond, to contribute to what I hope for, now and in the future, for children and society — the constant becoming of a more just and equitable world.

\section{References}

Berger, I. (2010). Extending the notion of pedagogical narration through Hannah Arendt's political thought. In V. Pacini-Ketchabaw (Ed.), Flows, rhythms, and intensities of early childhood education curriculum (pp. 57-76). New York, NY: Peter Lang.

Berger, I. (2015). Pedagogical narrations and leadership in early childhood education as thinking in moments of not knowing. Journal of the Canadian Association for Young Children, 40(1), 130-147.

Cannella, G. S. (1998). Early childhood education: A call for the construction of revolutionary images. In W. F. Pinar (Ed.) Curriculum: Toward new identities (pp. 157-184). New York, NY: Garland.

Cannella, G. S. (2008). Deconstructing early childhood education: Social justice and revolution. New York, NY: Peter Lang.

Dahlberg, G., \& Moss, P. (2005). Ethics and politics in early childhood education. New York, NY: RoutledgeFalmer.

Dahlberg, G., Moss, P., \& Pence, A. (2013). Beyond quality in early childhood education and care: Languages of evaluation ( ${ }^{\text {rd }}$ ed.). London, England: Routledge.

Deleuze, G., \& Guattari, F. (1987). A thousand plateaus: Capitalism and schizophrenia (B. Massumi, Trans.). Minneapolis, MN: University of Minnesota Press.

Government of British Columbia. (2008). British Columbia early learning framework. Victoria, BC: Ministry of Education, Ministry of Health, Ministry of Children and Family Development, \& British Columbia Early Learning Advisory Group.

Lenz Taguchi, H. (2010). Going beyond the theory/practice divide in early childhood education: Introducing an intra-active pedagogy. London and New York: Routledge.

MacNaughton, G. (2005). Doing Foucault in early childhood studies: Applying poststructural ideas. New York, NY: RoutledgeFalmer.

Rinaldi, C. (2006). In dialogue with Reggio Emilia: Listening, researching and learning. New York, NY: Routledge. 